\title{
道路橋床版の低周波域における振動性状について \\ DYNAMIC RESPONSE IN INFRASONIC FREQUENCY RANGE \\ OF HIGHWAY BRIDGE DECK SLABS
}

\author{
足立 義 雄* . 岡 村 宏一**.島 田 功*** \\ By Yoshio ADACHI, Hirokazu OKAMURA and Isao SHIMADA
}

\section{1. まえがき}

走行車両による道路橋床版の振動性状に関する理論的 研究は古くから行われ, 等方性単一板や, 直交異方性板 のモデルについての解析 ${ }^{1) \sim 6)}$, あるいは有限帯板法など

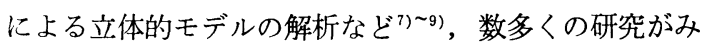
られる. しかし, これらのほとんどのものは, 主として 強度的な観点に立ったもので, 音響制御的な観点に立っ たものは数少ない. 最近, 土木の分野においても, 構造 物から発生する騒音の問題が, 環境問題の 1 つとして注 目されて抢り, 今後, この分野での研究の必要性が増大 するものと思われる.ここで, 音響制御的な観点に立っ て道路橋床版の振動特性をとらえようとすれば, それな りの解析上の配慮が加味されねばならない，たとえば特 に低周波音域においては, 橋梁の伸縮継手から誘発され る振動が問題になる場合もあり ${ }^{10)}$, 従来の解析例にみら れるような，単純支持などの簡単な条件の導入が許され ず,また, 床版と結合している骨組構造の補剛条件が十 分に考慮されねばならないことなどである.

本論文は, 以上のような観点を踏まえ, 解析手段とし て, 先に発表した 道路橋の立体解析法 ${ }^{11), 12)}$ を拡張した 手法を用い, 合成桁橋, $\mathrm{PC} \cdot \mathrm{T}$ 桁橋, 上路トラス橋の 3 橋について, 特に低周波域に打ける発振体としての鉄筋 コンクリートスラブの振動性状を探究したものである. まず, 前述のような伸縮継手の沈下, 床版と析組の有機 的関連, またトラス橋の場合には主構部のせん断変形な どを考虑した立体解析によって床版の固有振動のモード を詳細に求め, 次に, モーダルアナリシスによって, 走 行車両に上る床版の低周波域における振動応答を解析 し, 実測值との比較も行った.

$*$ 正会員 工修 建設省土木研究所 道路部

** 正会員 工博 大阪工業大学教授 土木工学科

*** 正会員 東洋技研コンサルタント（株）
得られた結果によれば, 従来指摘されているように, 道路橋床版の低周波域の振動性状には, 大別して, 橋梁 全体の振動にかかわるものと，伸縮継手より誘発される 振動にかかわるものとの 2 つのパターンが存在すること を立証できたと思う。

\section{2. 自由振動の立体解析}

\section{（1）桁組と合成される床版の振動方程式とその解}

図一1 に示寸床版要素の自由振動の微分方程式は面内 方向の慣性力を無視するとき, 次のように表わされる.

$$
\begin{aligned}
D\left(\frac{\partial^{4} W}{\partial x^{4}}\right. & \left.+2 \frac{\partial^{4} W}{\partial x^{2} \partial y^{2}}+\frac{\partial^{4} W}{\partial y^{4}}\right) \\
& +\rho h \frac{\partial^{2} W}{\partial t^{2}}=-Q_{u}-\frac{h}{2} \frac{\partial S_{u}}{\partial x} \\
h\left(\frac{\partial^{4} \Phi}{\partial \bar{x}^{4}}\right. & \left.+2 \frac{\partial^{4} \Phi}{\partial \bar{x}^{2} \partial y^{2}}+\frac{\partial^{4} \Phi}{\partial y^{4}}\right) \\
=\nu & \frac{\partial S_{u}}{\partial \bar{x}}-\frac{\partial^{2}}{\partial y^{2}} \int S_{u} d \bar{x}
\end{aligned}
$$

ここに, $D$ は床版の曲げ剛度, レはポアソン比, $h$ は 版厚, $\rho$ は床版の質量, $W$ はたわみ, $\Phi$ は面内力の応 力関数, $Q_{u}, S_{u}$ はそれぞれ, 桁組と床版の合成面に作 用する垂值, 水平方向の不静定力である.

式（1）の時間の項を周期関数により分離するために,

$$
\left.\begin{array}{l}
W=w \cos \omega t, \Phi=\phi \cos \omega t, \\
Q_{u}=q_{u} \cos \omega t, S_{u}=s_{u} \cos \omega t
\end{array}\right\}
$$
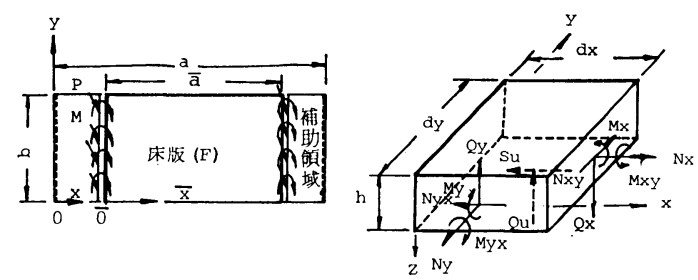

図一1＼cjkstart床版の諸元および微小要素 
と置き, 式 (1) に代入すると, 次の振動方程式を得る.

$$
\left.\begin{array}{rl}
D\left(\frac{\partial^{4} w}{\partial x^{4}}\right. & \left.+2 \frac{\partial^{4} w}{\partial x^{2} \partial y^{2}}+\frac{\partial^{4} w}{\partial y^{4}}\right) \\
& -\rho h \omega^{2} w=-q_{u}-\frac{h}{2} \frac{\partial s_{u}}{\partial x} \\
h\left(\frac{\partial^{4} \phi}{\partial \bar{x}^{4}}\right. & \left.+2 \frac{\partial^{4} \phi}{\partial \bar{x}^{2} \partial y^{2}}+\frac{\partial^{4} \phi}{\partial y^{4}}\right) \\
=\nu & \frac{\partial s_{u}}{\partial \bar{x}}-\frac{\partial^{2}}{\partial y^{2}} \int s_{u} d \bar{x}
\end{array}\right\}
$$

式（3）に含まれる諸量を次のような級数に展開する.

$$
\begin{gathered}
w=\sum_{m} \sum_{n} w_{m n} \sin \alpha_{m} x \sin \beta_{n} y \\
q_{u}=\sum_{m} \sum_{n} q_{m n} \sin \alpha_{m} x \sin \beta_{n} y \\
s_{u}=\sum_{m} \sum_{n} s_{m n} \cos \alpha_{m} x \sin \beta_{n} y \\
\phi=\sum_{m} \sum_{n} \phi_{m n} \sin \bar{\alpha}_{m} \bar{x} \sin \beta_{n} y \\
s_{u}=\sum_{m} \sum_{n} \bar{s}_{m n} \cos \bar{\alpha}_{m} \bar{x} \sin \beta_{n} y
\end{gathered}
$$

ここに, $\alpha_{m}=m \pi / a, \bar{\alpha}_{m}=m \pi / \bar{a}, \beta_{n}=n \pi / b$

$$
(m, n=1,2,3, \cdots)
$$

式（4）を式 (3) に代入すると, 周辺単純支持の場合の 特解 $w_{p}, \phi_{p}$ が次のように求まる。

$$
\left.\begin{array}{c}
w_{p}=\frac{1}{D} \sum_{m} \sum_{n} \frac{\frac{h}{2} \alpha_{m} s_{m n}-q_{m n}}{\left(\alpha_{m}^{2}+\beta_{n}^{2}\right)^{2}-\kappa^{2}} \sin \alpha_{m} x \sin \beta_{n} y \\
\phi_{p}=\frac{1}{h} \sum_{m} \sum_{n} \frac{\bar{\alpha}_{m}}{\left(\bar{\alpha}_{m}^{2}+\beta_{n}^{2}\right)^{2}}\left(\frac{\beta_{n}^{2}}{\bar{\alpha}_{m}^{2}}-\nu\right) \\
\cdot \bar{s}_{m n} \sin \bar{\alpha}_{m} \bar{x} \sin \beta_{n} y
\end{array}\right\}
$$

また, 式 (3) の同次方程式の解は, 図一1 を参照し て, 橋梁床版の相対 2 辺 $(y=0, y=b)$ を自由辺とし, 他の 2 辺 $(x=0, x=a)$ を単純支持とする 条件のもと

\begin{tabular}{|c|c|c|c|c|c|c|c|}
\hline \multicolumn{3}{|c|}{$y$ 方向の対称性 } & $\Gamma_{m}$ & $\Gamma_{m^{\prime}}$ & $\bar{\Gamma}_{m}$ & $\bar{\Delta}_{m}$ & $\bar{A}_{m}$ \\
\hline 正 & 対 & 称 & $\delta_{m}$ & $\delta_{m^{\prime}}$ & $\bar{\zeta}_{m}$ & $\bar{\delta}_{m}$ & $\bar{\varepsilon}_{m}$ \\
\hline 逆 & 対 & 称 & $1 / \delta_{m}$ & $1 / \delta_{m^{\prime}}$ & $\bar{\delta}_{m}$ & $\bar{\zeta}_{m}$ & $-\bar{\varepsilon}_{m}$ \\
\hline
\end{tabular}
で, 次のように与えられる.

$$
\left.\begin{array}{rl}
w_{c}=\frac{1}{D} \sum_{m} & \left(A_{m} \sinh \gamma_{m} y+B_{m} \cosh \gamma_{m} y\right. \\
& +C_{m} \sinh \gamma_{m}^{\prime} y \\
& \left.+D_{m} \cosh r_{m}^{\prime} y\right) \sin \alpha_{m} x \\
\phi_{c}=\frac{1}{h} \sum_{m} & \left(\bar{A}_{m} \sinh \bar{\alpha}_{m} y+\bar{B}_{m} \cosh \bar{\alpha}_{m} y\right. \\
& +\bar{C}_{m} \bar{\alpha}_{m} y \sinh \bar{\alpha}_{m} y \\
+ & \left.\bar{D}_{m} \bar{\alpha}_{m} y \cosh \bar{\alpha}_{m} y\right) \sin \bar{\alpha}_{m} \bar{x}
\end{array}\right\}
$$

ここに, $\gamma_{m}=\sqrt{\alpha_{m}{ }^{2}+\kappa}, \gamma_{m}{ }^{\prime}=\sqrt{\alpha_{m}{ }^{2}-\kappa}, \quad \kappa=\omega \sqrt{\rho h} / D$ となり $\omega$ は固有円振動数である. また, 積分定数 $A_{m}$ $\sim D_{m}, \bar{A}_{m} \sim \bar{D}_{m}$ は, 相対 2 辺 $(y=0, y=b)$ の境界条 件により定まるが， $y$ 方向の対称性を考慮することによ り, 次のような相互の関係を得る.

$$
\left.\begin{array}{l}
B_{m}=-\Gamma_{m} A_{m}, D_{m}=-\Gamma_{m}^{\prime} C_{m} \\
\bar{B}_{m}=-\bar{\Gamma}_{m} \bar{A}_{m}-\bar{A}_{m} \bar{C}_{m}, \bar{D}_{m}=-\bar{\Delta}_{m} \bar{C}_{m}
\end{array}\right\}
$$

ただし, $\Gamma_{m}, \Gamma_{m}{ }^{\prime}, \bar{\Gamma}_{m}, \bar{\Lambda}_{m}, \bar{\Delta}_{m}$ は表一1 に示すものと
表一1 対称性による分類

なる. 式（7）を用いると，相対 2 辺が自由な場合の 積 分定数は次のようになる.

$$
\left.\begin{array}{l}
A_{m}=-\Gamma_{m}{ }^{\prime}\left(\gamma_{m}{ }^{2}-\nu \alpha_{m}{ }^{2}\right) \frac{V_{m}}{X_{m}} \\
C_{m}=\Gamma_{m}\left(\gamma_{m}{ }^{2}-\nu \alpha_{m}{ }^{2}\right) \frac{V_{m}}{X_{m}} \\
\bar{A}_{m}=-\frac{\bar{A}_{m} T_{m}}{\bar{X}_{m}}, \bar{C}_{m}=\frac{\bar{\Gamma}_{m} T_{m}}{\bar{X}_{m}}
\end{array}\right\}
$$

ただし，

$$
\begin{aligned}
X_{m}= & \Gamma_{m}\left(r_{m}{ }^{2}-\nu \alpha_{m}{ }^{2}\right)\left\{\gamma_{m}{ }^{2}-(2-\nu) \alpha_{m}{ }^{2}\right\} \gamma_{m}{ }^{\prime} \\
& -\Gamma_{m}{ }^{\prime}\left(\gamma_{m}{ }^{2}-\nu \alpha_{m}{ }^{2}\right)\left\{\gamma_{m}{ }^{2}-(2-\nu) \alpha_{m}{ }^{2}\right\} \gamma_{m} \\
\bar{X}_{m}= & -\left(\bar{\Gamma}_{m} \bar{\Delta}_{m}+\bar{A}_{m}\right) \bar{\alpha}_{m}{ }^{2} \\
V_{m}= & -D\left\{\frac{\partial^{3} w_{p m}}{\partial y^{3}}+(2-\nu) \frac{\partial^{3} w_{p m}}{\partial x^{2} \partial y}\right\}_{y=0} \\
T_{m}= & -h\left(\frac{\partial^{2} \phi_{p m}}{\partial \bar{x} \partial y}\right)_{y=0}
\end{aligned}
$$

結局，式（3）の解は重ね合わせにより，

$$
w=w_{p}+w_{c}, \phi=\phi_{p}+\phi_{c}
$$

となる. なお, 橋梁端部の伸縮継手 $(\bar{x}=0, \bar{x}=\bar{a})$ の条 件は，(3）に述べるように, 式（9）を素解とし，いわ ゆる積分法によって与える.

\section{（2）床版之标の相互間に作用するカと境界調整力の 分布の近似}

本解法では，床版と桁の相互間に作用する不静定力の 分布を, 先に発表した解法 ${ }^{12)}$ と同様に, 細かく分割され た区間で等分布する垂直力と水平力の重ね合わせによっ て与える. すなわち，図一2 に示すように，床版と主 桁の合成面にとった小領域 $\left(2 c_{k} \times 2 d_{l}\right)$ に, 強さ $q_{k l}$, $s_{k l}$ の垂直力と水平力を作用させる. さらに, これらの 力のほかに, 伸縮継手の境界条件を切り出すための調整 力として, 床版に設けた解析上の補助領域内の小さい分 割区間に, 強さ $p_{r}, m_{r}$ の線荷重と線モーメントを作用 させる.このような分布荷重を重ね合わせた形で, 床版 に作用する力の分布を近似すると, 式 (4), 式 (5) に含 まれるフーリエ係数を次のように与えることができる.

$$
\left.\begin{array}{rl}
q_{m n}= & \frac{q_{k l}}{a b} \frac{16}{\alpha_{m} \beta_{n}} \sin \alpha_{m} x_{k} \sin \alpha_{m} c_{k} \sin \beta_{n} y_{l} \sin \beta_{n} d_{l} \\
& -\frac{p_{r}}{a b} \frac{8}{\beta_{n}} \sin \alpha_{m} x_{b} \sin \beta_{n} y_{r} \sin \beta_{n} d_{r} \\
& -\frac{m_{r}}{a b} \frac{8 \alpha_{m}}{\beta_{m}} \cos \alpha_{m} x_{b} \sin \beta_{n} y_{r} \sin \beta_{n} d_{r}
\end{array}\right\}
$$




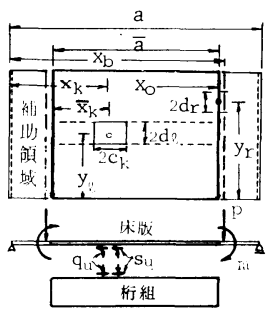

(a) 不静定力上境界調整力

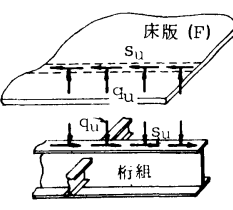

(b) 不静定力0分开

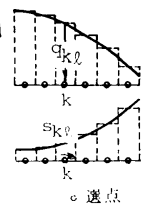

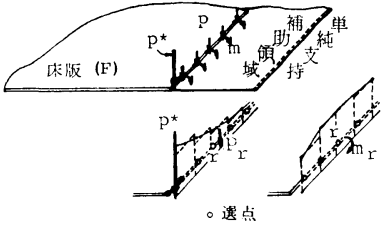

(c) 境界淍整力の分有

\section{図一2 床版に作用する力の分布の近似}

$s_{m n}=\frac{s_{k l}}{a b} \frac{16}{\alpha_{m} \beta_{n}} \cos \alpha_{m} x_{k} \sin \alpha_{m} c_{k} \sin \beta_{n} y_{l} \sin \beta_{n} d_{l}$ $\bar{s}_{m n}=\frac{s_{k l}}{\bar{a} b} \frac{16}{\bar{\alpha}_{m} \beta_{n}} \cos \bar{\alpha}_{m} \bar{x}_{k} \sin \bar{\alpha}_{m} c_{k} \sin \beta_{n} y_{l} \sin \beta_{n} d_{l}$

ここに, $\operatorname{pr}$ の係数は $q_{k l}$ の係数の極限をとり，作用位 置と分布幅を変更して求まる. また, $m_{r}$ の係数は $p_{r}$ の係数に偶力としての微分操作を加えて求まる.

式（10）を式 (5) に代入し, 特解 $w_{p}, \phi_{p}$ が得られ,
式（7）（8）より式（6）の補足解の積分定数が定まる. よって, 式 (9) の $w, \phi$ は, 次の形に得られる.

$$
\left.\begin{array}{l}
w=\sum_{k} \sum_{l}\left(q_{k l} G_{k l}+s_{k l} H_{k l}\right)+\sum_{r}\left(p_{r} I_{r}+m_{r} J_{r}\right) \\
\phi=\sum_{k} \sum_{l} s_{k l} L_{k l}
\end{array}\right\}
$$

上式中の係数は，特解と補足解のそれぞれの係数の和で あり，不静定力の位置と区間分布の範囲を定めれば，床 版の任意点に対する影響係数として与えられる.これら の諸係数は, 次のようになる.

$$
\begin{aligned}
& G_{k l}=-\sum_{m} \sum_{n}\left(\sin \beta_{n} y+U_{m}^{c}\right) \chi_{m n} \sin \alpha_{m} x_{k} \sin \alpha_{m} c_{k} \sin \beta_{n} y_{l} \sin \beta_{n} d_{l} \sin \alpha_{m} x \\
& H_{k l}=\frac{h}{2} \sum_{m} \sum_{n}\left(\sin \beta_{n} y+U_{m}^{c}\right) \alpha_{m} \chi_{m n} \cos \alpha_{m} x_{k} \sin \alpha_{m} c_{k} \sin \beta_{n} y_{l} \sin \beta_{n} d_{l} \sin \alpha_{m} x \\
& I_{r}=\sum_{m} \sum_{n}\left(\sin \beta_{n} y+U_{m}^{c}\right) \frac{\alpha_{m}}{2} \chi_{m n} \sin \alpha_{m} x_{b} \sin \beta_{n} y_{r} \sin \beta_{n} d_{r} \sin \alpha_{m} x \\
& J_{r}=\sum_{m} \sum_{n}\left(\sin \beta_{n} y+U_{m}^{c}\right) \frac{\alpha_{m}{ }^{2}}{2} \chi_{m n} \cos \alpha_{m} x_{b} \sin \beta_{n} y_{r} \sin \beta_{n} d_{r} \sin \alpha_{m} x \\
& L_{k l}=\sum_{m} \sum_{n}\left(\sin \beta_{n} y+\bar{U}_{m}{ }^{c}\right) \bar{\alpha}_{m} \bar{\chi}_{m n} \cos \bar{\alpha}_{m} \bar{x}_{k} \sin \bar{\alpha}_{m} c_{k} \sin \beta_{n} y_{l} \sin \beta_{n} d_{l} \sin \bar{\alpha}_{m} \bar{x}
\end{aligned}
$$

ただし，

$$
\begin{aligned}
\chi_{m n} & =\frac{1}{D\left\{\left(\alpha_{m}^{2}+\beta_{n}^{2}\right)^{2}-\kappa^{2}\right\}} \frac{16}{a b \alpha_{m} \beta_{n}} \\
\bar{\chi}_{m n} & =\frac{\frac{\beta_{n}^{2}}{\bar{\alpha}_{m}^{2}}-\nu}{h\left(\bar{\alpha}_{m}^{2}+\beta_{n}^{2}\right)^{2}} \frac{16}{\bar{a} b \bar{\alpha}_{m} \beta_{n}}
\end{aligned}
$$

$U_{m}{ }^{c}, \bar{U}_{m}{ }^{c}$ は, 補足解に関するもので, 式 (7), (8)よ り積分定数を定め式 (9) に代入して, 座標 $y$ の項をま とめたものである. 式 (12) は, $m, n$ に関する 2 重級 数となるが，総和公式を用いて単級数と代数式に書きか えられ，級数計算は収束の速いものとなる. 総和公式の 基本式として次のものを示しておく.

$$
\left.\begin{array}{r}
\sum_{n=1,3,5 \cdots} \frac{\sin n \pi Y}{n\left\{\left(\lambda^{2} m^{2}+n^{2}\right)^{2}-\Omega^{2}\right\}}=\frac{1}{4 R_{m}^{2} R_{m}{ }^{2}} \\
+\frac{\pi}{8 \Omega}\left[\frac{1}{R_{m}^{2}}\left\{\frac{\left.\sinh R_{m} \pi(1-Y)+\sinh R_{m} \pi Y\right\}}{\sinh R_{m} \pi}\right\}\right. \\
\left.-\frac{1}{R_{m}^{\prime 2}}\left\{\frac{\sinh R_{m}^{\prime} \pi(1-Y)+\sinh R_{m}{ }^{\prime} \pi Y}{\sinh R_{m}^{\prime} \pi}\right\}\right] \\
\sum_{n=2,4,6 \ldots} \frac{\sin n \pi Y}{n\left\{\left(\lambda^{2} m^{2}+n^{2}\right)^{2}-\Omega^{2}\right\}}=\frac{1}{4 R_{m}^{2} R_{m}^{\prime 2}} \\
+\frac{\pi}{8 \Omega}\left[\frac{1}{R_{m}^{2}}\left\{\frac{\sinh R_{m} \pi(1-Y)-\sinh R_{m} \pi Y}{\sinh R_{m} \pi}\right\}\right.
\end{array}\right\}
$$

$$
\left.-\frac{1}{R_{m}^{\prime 2}}\left\{\frac{\sinh R_{m}^{\prime} \pi(1-Y)-\sinh R_{m}^{\prime} \pi Y}{\sinh R_{m}^{\prime} \pi}\right\}\right] \mid
$$

ここに, $0 \leq Y \leq 1, R_{m}=\sqrt{\lambda^{2} m^{2}+\Omega}, R_{m}{ }^{\prime}=\sqrt{\lambda^{2} m^{2}-\Omega}$ であり, 式 (13) を微分することにより, 解析に必要な 諸式が求まる.

\section{（3）床版端部（伸縮継手）の境界条件}

上路トラス橋のように, 端対傾構を通して支承に力が 伝達されるような場合には, 床版端部に沈下を生じ, こ れが低周波域における振動性状に大きく影響するといわ れている ${ }^{10)}$.ここでは，このような伸縮継手の条件をよ り忠実に導入するため, 曲げに対して自由な境界条件を 与える（軸力に対しては自由の条件を満足しており，前 述の解析上の補助領域を設けていない).

いま, 図一2(c) に示すような, 相対 2 辺自由, 2 辺単 純支持の単一板から, 端部において自由な境界条件を満 足する板 $F$ (実領域) を, いわゆる積分法によって切り 出す. そこで, 板 $F$ の外側に設けた 解析上の補助領域 に図一2(c) に示した線荷重 $p_{r}$, 線モーメント $m_{r}$, お 
よび集中力 $p^{*}$ を作用させ, 境界条件として, 端部境界 線上にとった各分割区間の中点 $\left(x_{0}, y_{r}\right)$ で自由な条 件, および隅角点 $\left(x_{0}, 0\right),\left(x_{0}, b\right)$ で偶角点定着力が零 になるものを与える. すなわち

$$
\left.\begin{array}{l}
M_{x}\left(x_{0}, y_{r}\right)=V_{x}\left(x_{0}, y_{r}\right)=0 \\
M_{x y}\left(x_{0}, 0\right)=M_{x y}\left(x_{0}, b\right)=0
\end{array}\right\}
$$

ここで, $M_{x}, V_{x}, M_{x y}$ はそれぞれ, 曲げモーメント, 換算せん断力, ねじりモーメントである.

式（14）は, 端部境界辺上にとったすべての選点と隅 角点で成立し, 未知量 $p_{r}, m_{r}, p^{*}$ を定める連立方程式 となる.

\section{（4）桁組の解}

床版と主桁の相互間に受け渡される不静定力の分布を

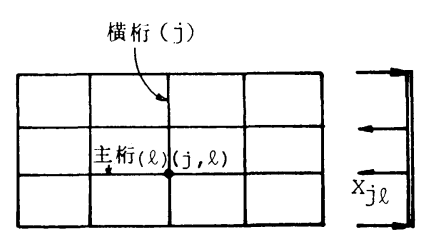
前述のように矩形分布 荷重の重ね合わせによ って表わせば，桁組の 解は, 図一3 に示すよ らな格子構造を解くこ とによって容易に求ま

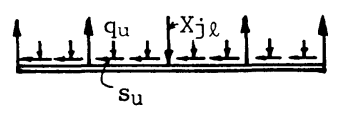

図一3桁組に作用する力 る.また，トラス橋の 場合も, 主構部を等価 剛性（伸び, 曲げ, お よびせん断剛性)をもつ桁に置換すれば格子構造となる.

ここで, 曲げとせん断変形を考慮したはりの式を取り 出すと, 次のとおりである.

$$
\begin{aligned}
& E I \frac{d^{4} w}{d \bar{x}^{4}}+\frac{E I \rho A}{G J} \omega^{2} \frac{d^{2} w}{d \bar{x}^{2}}-\rho A \omega^{2} w \\
& \quad=\left\{\left(1-\frac{E I}{G J} \frac{d^{2}}{d \bar{x}^{2}}\right) q_{n}-e \frac{d s_{u}}{d \bar{x}}\right\} \times 2 d \cdots
\end{aligned}
$$

ここに, $E I$ は曲げ剛性, $G J$ はせん断剛性, $e$ は合成 面とはりの重心位置との距離, $\rho A$ は単位長さ当たりの 質量, $q_{\boldsymbol{u}}, s_{\boldsymbol{u}}$ はそれぞれ, 床版との間で受け渡される不 静定力である. 式 (15) は, 円振動数 $\omega$ で振動する場 合の桁の振動方程式となる. 式 (15) の解を

$$
w=w_{o p}+w_{o c}
$$

とおく.ここで $w_{o p}$ は特解, $w_{o c}$ は補足解を表わし, $w_{o p}$ は単純ばりの解として, 図一2, 3 の不静定力に対 しては次のように与えられる.

$$
\begin{aligned}
w_{o p}= & \frac{1}{2 E I} \frac{1}{\kappa_{1}{ }^{2}+\kappa_{2}{ }^{2}}\left\{\left(\frac{1}{\kappa_{1}}+\frac{E I}{G J} \kappa_{1}\right)\right. \\
& \cdot\left(2 d q_{k l} \int_{\bar{x}_{k}-c_{k}}^{\bar{x}_{k}+c_{k}} N_{1} d \bar{x}_{i}-X_{j l} N_{1 j}\right) \\
& +\left(\frac{1}{\kappa_{2}}-\frac{E I}{G J} \kappa_{2}\right) \\
& \cdot\left(2 d q_{k l} \int_{\bar{x}_{k}-c_{k}}^{\bar{x}_{k}+c_{k}} N_{2} d \bar{x}_{i}-X_{j l} N_{2 j}\right) \\
& \left.+2 d s_{k l} e \int_{\bar{x}_{k}-c_{k}}^{\bar{x}_{k}+c_{k}} \frac{\partial}{\partial x_{i}}\left(\frac{1}{\kappa_{1}} N_{1}+\frac{1}{\kappa_{2}} N_{2}\right) d \bar{x}_{i}\right\}
\end{aligned}
$$

ここに, $N_{1}=\frac{\cos \kappa_{1}\left(\bar{a}-\bar{x}_{i}-\bar{x}\right)-\cos \kappa_{1}\left(\bar{a}-\left|\bar{x}_{i}-\bar{x}\right|\right)}{\sin \kappa_{1} \bar{a}}$

$$
N_{2}=\frac{\cosh \kappa_{2}\left(\bar{a}-\bar{x}_{i}-\bar{x}\right)-\cosh \kappa_{2}\left(\bar{a}-\left|\bar{x}_{i}-\bar{x}\right|\right)}{\sinh \kappa_{2} \bar{a}}
$$

また，

$$
\begin{aligned}
& \kappa_{1}=\sqrt{\frac{\rho A \omega^{2}}{2 G J}+\sqrt{\left(\frac{\rho A \omega^{2}}{2 G J}\right)^{2}+\frac{\rho A \omega^{2}}{E I}}} \\
& \kappa_{2}=\sqrt{-\frac{\rho A \omega^{2}}{2 G J}+\sqrt{\left(\frac{\rho A \omega^{2}}{2 G J}\right)^{2}+\frac{\rho A \omega^{2}}{E I}}}
\end{aligned}
$$

であり, $X_{j l}$ は桁組の格子点の不静定力である.

一方, $w_{o c}$ を材端モーメントが零, 材端変位が $w_{o}(o)$ $w_{o}(\bar{a})$ となる形で与えると，

$$
\begin{aligned}
w_{o c}= & \frac{1}{\kappa_{1}^{2}+\kappa_{2}^{2}}\left[( \kappa _ { 2 } ^ { 2 } + \frac { \rho A \omega ^ { 2 } } { G J } ) \left\{w_{o}(o) \cos \kappa_{1} \bar{x}\right.\right. \\
& \left.-\left(w_{o}(o) \cos \kappa_{1} \bar{a}-w_{o}(\bar{a})\right) \frac{\sin \kappa_{1} \bar{x}}{\sin \kappa_{1} \bar{a}}\right\} \\
& +\left(\kappa_{1}^{2}-\frac{\rho A \omega^{2}}{G J}\right)\left\{w_{o}(o) \cosh \kappa_{2} \bar{x}\right. \\
& \left.\left.-\left(w_{o}(o) \cosh \kappa_{2} \bar{a}-w_{0}(\bar{a})\right) \frac{\sinh \kappa_{2} \bar{x}}{\sinh \kappa_{2} \bar{a}}\right\}\right]
\end{aligned}
$$

断面力は次式のとおりである.

$$
\left.\begin{array}{l}
M=-E I \frac{d^{2} w}{d \bar{x}^{2}}-\frac{E I}{G J}\left(\rho A \omega^{2} w+q_{u}\right) \\
Q=-E I \frac{d^{3} w}{d \bar{x}^{3}}-\frac{E I}{G J} \rho A \omega^{2} \frac{d w}{d \bar{x}}-e s_{u}
\end{array}\right\}
$$

また, 主桁と横桁の結合条件は, 両者の間に作用する不 静定力 $X_{j l}$ に対応して,

$$
w^{l}\left(\bar{x}_{j}\right)=w^{j}\left(y_{l}\right)
$$

で与えられる連立方程式となる. ここに, $w^{l}\left(\bar{x}_{j}\right), w^{j}$ $\left(y_{l}\right)$ はそれぞれ主桁および横桁の結合点の変位である.

\section{（5）床版と桁組の合成条件}

図一2 (a),(b) を参照して, 合成条件は, 床版と主桁 の合成面上に作用する不静定力の各分割区間の中心にと った選点 $\left(x_{k}, y_{l}\right)$ において, 次の連続条件の形で与え られる.

$$
\left.\begin{array}{l}
w\left(x_{k}, y_{l}\right)=w^{l}\left(\bar{x}_{k}\right) \\
u\left(\bar{x}_{k}, y_{l}\right)_{z=0}=u^{l}\left(\bar{x}_{k}\right)
\end{array}\right\}
$$

ここに, $u^{l}$ は平面保持の仮定により, 主桁の変形から 定まる床版中央面での水平変位である.

式（21）は合成面上にとったすべての選点で成立し, 不静定力 $q_{k l}, s_{k l}$ を定める連立方程式となる.

\section{（6）固有振動数之固有モード}

前述のように, 式 (14), (20), (21) は, 不静定力 $p_{r}$, $m_{r}, p^{*}, q_{k l}, s_{k l}, X_{j l}$ を定める 連立方程式を形成し, 
円振動数 $\omega$ についての 特性方程式を与えることになる が，本解析では， $\omega$ を逐次変化させて行列式を零にする 固有円振動数を追跡し，固有モードを求めた。

\section{3. 固有振動モードの直交性}

2. で述べた 固有モードは 無限に存在するが，それら を $\varphi_{1}, \varphi_{2}, \varphi_{3} \cdots$ とすると次の関係を得る.

$$
\begin{aligned}
D \varphi_{f} & \left(\frac{\partial^{4} \varphi_{g}}{\partial x^{4}}+2 \frac{\partial^{4} \varphi_{g}}{\partial x^{2} \partial y^{2}}+\frac{\partial^{4} \varphi_{g}}{\partial y^{4}}\right) \\
& -\rho h \omega_{g}^{2} \varphi_{f} \varphi_{g}+\varphi_{f}\left(q_{u g}+\frac{h}{2}-\frac{\partial s_{u g}}{\partial x}\right)=0
\end{aligned}
$$

ここに, $f, g=1,2,3 \cdots$

式 (22) と，またその $f, g$ を入れ換えたものとの差 をとり, 床版 $F$ の全面積 $A$ にわたって積分すると次 式を得る。

$$
\begin{aligned}
D \int_{A} & \left\{\varphi_{f}\left(\Delta \Delta \varphi_{g}\right)-\varphi_{g}\left(\Delta \Delta \varphi_{f}\right)\right\} d F \\
& +\int_{A}\left\{\varphi_{f}\left(q_{u g}+\frac{h}{2} \frac{\partial s_{u g}}{\partial x}\right)\right. \\
& \left.-\varphi_{g}\left(q_{u f}+\frac{h}{2} \frac{\partial s_{u f}}{\partial x}\right)\right\} d F \\
& =\rho h\left(\omega_{g}{ }^{2}-\omega_{f}{ }^{2}\right) \int_{A} \varphi_{f} \varphi_{g} d F
\end{aligned}
$$

ただし, $\Delta=\frac{\partial^{2}}{\partial x^{2}}+\frac{\partial^{2}}{\partial y^{2}}$

式 (23) の左辺第 1 項は相反定理により零になる.さ らに左辺第 2 項を析組との合成条件を考虑して恋形する と次のようになる.

$$
\begin{aligned}
\int_{A} & \left\{\varphi_{f}\left(q_{u g}+\frac{h}{2} \frac{\partial s_{u g}}{\partial x}\right)\right. \\
& \left.-\varphi_{g}\left(q_{u f}+\frac{h}{2} \frac{\partial s_{u f}}{\partial x}\right)\right\} d F \\
& =-\left(\omega_{g}{ }^{2}-\omega_{f}^{2}\right)\left\{\sum_{l}\left(\rho_{l} A_{l} \int_{0}^{\bar{a}} \varphi_{f} \varphi_{g} d \bar{x}\right)_{l}\right. \\
& \left.+\sum_{j}\left(\rho_{j} A_{j} \int_{0}^{b} \bar{\varphi}_{f} \bar{\varphi}_{g} d y\right)_{j}\right\} \quad \cdots \cdots \cdots \cdots \cdots
\end{aligned}
$$

ここに, $\rho_{l} A_{l}, \rho_{j} A_{j}$ はそれぞれ主桁および横桁の単位 長さ当たりの質量, $\bar{\varphi}$ は横桁のモード, $l, j$ はそれぞれ 主桁および横桁の指標を表わす.

式（24）を式（23）に代入すると，

$$
\begin{aligned}
o= & \left(\omega_{g}^{2}-\omega_{f}^{2}\right)\left\{\rho h \int_{A} \varphi_{f} \varphi_{g} d A\right. \\
& +\sum_{l}\left(\rho_{l} A_{l} \int_{0}^{\bar{a}} \varphi_{f} \varphi_{g} d \bar{x}\right)_{l} \\
& \left.+\sum_{j}\left(\rho_{j} A_{j} \int_{0}^{b} \bar{\varphi}_{f} \bar{\varphi}_{g} d y\right)_{j}\right\}
\end{aligned}
$$

となり, $\theta=\rho h \int_{A} \varphi_{f} \varphi_{g} d F+\sum_{l}\left(\rho_{l} A_{l} \int_{0}^{\bar{a}} \varphi_{f} \varphi_{g} d \bar{x}\right)_{l}$

$$
+\sum_{j}\left(\rho_{j} A_{j} \int_{0}^{b} \bar{\varphi}_{f} \bar{\varphi}_{g} d y\right)_{j}
$$

とおけば， $\omega_{f} \neq \omega_{g}$ のとき $\theta$ は零となり,$f=g$ のと きのみ零でない值をもつことになる.すなわち式（25） は，床版と桁組との合成構造における $\varphi_{f}, \varphi_{g}$ の直交性 を示している.

ところで, 固有モード $\varphi_{f}$ の大きさは自由に決まるの で，正規化した固有モードは次式より定まる。

$$
\begin{gathered}
\rho h \int_{A} \varphi_{f^{2}} d F+\sum_{l}\left(\rho_{l} A_{l} \int_{0}^{a} \varphi_{f^{2}} d \bar{x}\right)_{l} \\
+\sum_{j}\left(\rho_{j} A_{j} \int_{0}^{b} \bar{\varphi}_{f^{2}} d y\right)_{j}=1 \quad \cdots
\end{gathered}
$$

\section{4. 走行車両による床版の動的応答}

\section{（1）床版の強制振動方程式とその解}

曲げ振動の方程式は次の上らになる。

$$
\begin{aligned}
& D\left(\frac{\partial^{4} W}{\partial x^{4}}+2 \frac{\partial W^{4}}{\partial x^{2} \partial y^{2}}+\frac{\partial W^{4}}{\partial y^{4}}\right)+2 \eta \frac{\partial W}{\partial t} \\
& \quad+\rho h \frac{\partial^{2} W}{\partial t^{2}}+Q_{u}+\frac{h}{2} \frac{\partial S_{u}}{\partial x}=p_{0} \cdots \cdots \cdots
\end{aligned}
$$

ここに, $Q_{u}, S_{u}$ は主析と床版との合成面に作用寸る不 静定力, $\eta$ は減衰率である. なお $p_{0}$ は走行荷重の強さ を表わし, 本解析では一定の強さの移動荷重として扱 い，車両のばねの影響は考慮していない，

式 (25) において, 固有モード $\varphi_{f}(x, y)$ の直交性を 示した.したがって, 式 (28) の解 $W(x, y, t)$ が式 (27) の正規化した $\varphi_{f}$ で展開できるものとして，

$$
W(x, y, t)=\sum_{f=1}^{\infty} \varphi_{f}(x, y) \xi_{f}(t)
$$

のよらに置く．式（29）を式（28）に代入すると

$$
\begin{aligned}
\sum_{f=1}^{\infty}\left\{D\left(\Delta \Delta \varphi_{f}\right) \xi_{f}+2 \eta \varphi_{f} \frac{\partial \xi_{f}}{\partial t}+\rho h \varphi_{f} \frac{\partial^{2} \xi_{f}}{\partial t^{2}}\right\} \\
\quad+Q_{u}+\frac{h}{2} \frac{\partial S_{u}}{\partial x}=p_{0} \ldots \ldots \ldots \ldots \ldots \ldots \ldots \ldots . \cdots \cdots
\end{aligned}
$$

となる.ここに， $\varphi_{f}$ は床版の固有モードであり，式 (3) の第 1 式より

$$
D\left(\Delta \Delta \varphi_{f}\right)-\rho h \omega_{f}^{2} \varphi_{f}=-q_{u f}-\frac{h}{2} \frac{\partial s_{u f}}{\partial x} . .
$$

であるから，これを式（30）に代入すると次のようにな る.

$$
\begin{aligned}
\sum_{f=1}^{\infty} & \left\{\rho h\left(\omega_{f^{2} \xi_{f}}+\frac{2 \eta}{\rho h} \frac{d \xi_{f}}{d t}+\frac{d^{2} \xi_{f}}{d t^{2}}\right) \varphi_{f}\right. \\
& \left.-\left(q_{u f}+\frac{h}{2} \frac{\partial s_{u f}}{\partial x}\right) \xi_{f}\right\}+Q_{u}+\frac{h}{2} \frac{\partial S_{u}}{\partial x}=p_{0}
\end{aligned}
$$

ここで，固有モードの直交性を利用するため，上式の 両辺に $\varphi_{g}$ を乘じ, 床版 $F$ の全面積にわたって積分す る. また, $q_{u f}, s_{u f}$ には固有振動モードにおける桁組 との合成条件を， $Q_{u}, S_{\boldsymbol{u}}$ には式（29）のたわみ式にお ける桁組との合成条件を用いることにより次式を得る. 


$$
\begin{aligned}
\sum_{f} \sum_{g}\left(\omega_{f}^{2} \xi_{f}+2 \bar{\eta} \frac{d \xi_{f}}{d t}+\frac{d^{2} \xi_{f}}{d t^{2}}\right) \\
\quad \times\left\{\rho h \int_{A} \varphi_{f} \varphi_{g} d F+\sum_{l}\left(\rho_{l} A_{l} \int_{0}^{\bar{a}} \varphi_{f} \varphi_{g} d \bar{x}\right)_{l}\right. \\
\left.\quad+\sum_{j}\left(\rho_{j} A_{j} \int_{0}^{b} \bar{\varphi}_{f} \bar{\varphi}_{g} d y\right)_{j}\right\} \\
\quad=\sum_{g} \int_{A} p_{0}(x, y, t) \varphi_{g} d F \cdots \cdots \cdots \cdots \cdots(33)
\end{aligned}
$$

上式は, 式 (25) の固有モードの直交性, ならびに式 （27）の正規化した固有モードを用いることにより, 次 のような強制振動の運動方程式に書き換えられる.

$$
\frac{d^{2} \xi_{f}}{d t^{2}}+2 \bar{\eta} \frac{d \xi_{f}}{d t}+\omega_{f}{ }^{2} \xi_{f}=\int_{A} p_{0} \varphi_{f} d F
$$

ここに, $\bar{\eta}$ は合成構造の減衰率である. なお, 対数減衰 率 $\bar{\delta}$ との間には, $\bar{\delta}=2 \pi \bar{\eta} /\left(\omega_{f}^{2}-\bar{\eta}^{2}\right)^{1 / 2}$ の関係がある.

式 (34) の解は次のように与えられる.

$$
\begin{aligned}
\xi_{f}= & \frac{e^{-\bar{\eta} t}}{\bar{\omega}_{f}}\left[\sin \bar{\omega}_{f} t \int\left\{e^{\bar{\eta}_{f} t} \cos \bar{\omega}_{f} t\left(\int_{A} p_{0} \varphi_{f} d F\right)\right\} d t\right. \\
& \left.-\cos \bar{\omega}_{f} t \int\left\{e^{\bar{\eta} t} \sin \bar{\omega}_{f} t\left(\int_{A} p_{0} \varphi_{f} d F\right)\right\} d t\right] \\
& +e^{-\bar{\eta} t}\left(A_{f} \cos \bar{\omega}_{f} t+B_{f} \sin \bar{\omega}_{f} t\right) \cdots \cdots \cdots \cdots(35)
\end{aligned}
$$

ただし, $\bar{\omega}_{f}=\omega_{f}\left(1-\frac{\bar{\eta}^{2}}{\omega_{f}^{2}}\right)^{1 / 2}$ である.

式（35）を式（29）に代入することにより，強制振動 のたわみ応答の解が得られる. また積分定数 $A_{f}, B_{f}$ は応答解析の初期条件（たわみ,たわみ速度）より定ま
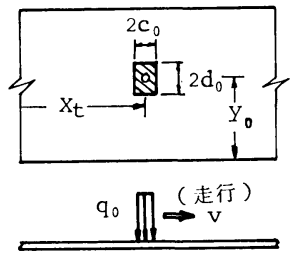

（a）走行荷重

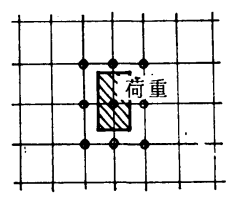

(b) 振動モードの解析点ネットと 荷重近傍の代表点 ( 9 点)

\section{図-4 走行荷重と振動モード の解析点}

$$
\begin{aligned}
\varphi_{f}= & a_{1 f}+a_{2 f} x+a_{3 f} x^{2}+a_{4 f} y+a_{5 f} y^{2} \\
& +a_{6} f x y+a_{7} x^{2} y+a_{8} f x y^{2}+a_{9} f x^{2} y^{2}
\end{aligned}
$$

これより,

$$
\begin{aligned}
& \int_{A} p_{0} \varphi_{f} d F=2 q_{0}\left\{2 D_{1} c_{o}+2 D_{2 f} x_{t} c_{o}\right. \\
& \left.+\frac{2}{3} D_{3} c_{o}\left(3 x_{t}^{2}+c_{0}^{2}\right)\right\}
\end{aligned}
$$

ここに，

$$
\begin{aligned}
& D_{1 f}=a_{1 f} d_{o}+a_{4 f} d_{o} y_{o}+\frac{1}{3} a_{5 f} d_{o}\left(3 y_{o}{ }^{2}+d_{o}{ }^{2}\right) \\
& D_{2 f}=a_{2 f} d_{o}+a_{6 f} d_{o} y_{o}+\frac{1}{3} a_{8 f} d_{o}\left(3 y_{o}{ }^{2}+d_{o}{ }^{2}\right) \\
& D_{3 f}=a_{3 f} d_{o}+a_{7 f} d_{o} y_{o}+\frac{1}{3} a_{9 f} d_{o}\left(3 y_{o}{ }^{2}+d_{o}{ }^{2}\right)
\end{aligned}
$$

図一4 (a) に示すように, 輪荷重 (強さ; $q_{o}$, 分布面 積 ; $2 c_{o} \times 2 d_{o}$ ) が橋軸方向に一定速度 $v$ で移動する場 合, 荷重位置は $x_{t}=x_{o}+v t$ で表わされ, 走行荷重によ るたわみ応答の式は次のようになる.

$$
\begin{aligned}
& w(x, y, t)=\sum_{f=1}^{\infty}\left[\frac { 1 } { \omega _ { f } ^ { 2 } } \sum _ { i = 1 } ^ { n } 2 q _ { o i } \left\{E_{1 i f}+E_{2 i f} \cdot\right.\right. \\
& \left.\cdot\left(t-\frac{2 \bar{\eta}}{\omega_{f}^{2}}\right)+E_{3 i f}\left(t^{2}-\frac{2}{\bar{\omega}_{f}^{2}}-\frac{4 \bar{\eta}}{\omega_{f}^{2}} t+\frac{8 \bar{\eta}^{2}}{\omega_{f}^{4}}\right)\right\} \\
& \left.+e^{-\bar{\eta} t}\left(A_{f} \cos \bar{\omega}_{f} t+B_{f} \sin \bar{\omega}_{f} t\right)\right] \varphi_{f} \cdots(38)
\end{aligned}
$$

ここに,

$$
\begin{aligned}
E_{1 i f}= & \left(2 D_{1 f} c_{o}+\frac{2}{3} D_{3 f} c_{o}{ }^{3}+2 D_{2 f} c_{o} x_{o}\right. \\
& \left.+2 D_{3 f} c_{o} x_{o}{ }^{2}\right)_{i} \\
E_{2 i f}= & 2\left(D_{2 f} c_{o}+2 D_{3 f} c_{o} x_{o}\right)_{i} v \\
E_{3 i f}= & 2\left(D_{3 f} c_{o}\right)_{i} v^{2}
\end{aligned}
$$

$i$ は $n$ 個の荷重の指標である.

いま, 初期条件として, $t=0$ で $\xi_{f}(0), \dot{\xi}_{f}(0)$ が与え られるとき, 積分定数 $A_{f}, B_{f}$ は次のようになる.

$$
\begin{aligned}
A_{f}= & \xi_{f}(0)-\frac{1}{\omega_{f}^{2}} \sum_{i=1}^{n} 2 q_{o i}\left\{E_{1 i f}-\frac{2 \bar{\eta} E_{2 i f}}{\omega_{f}^{2}}\right. \\
& \left.-\frac{2 E_{3 i f}}{\omega_{f}^{2}}\left(1-\frac{4 \bar{\eta}^{2}}{\omega_{f}^{2}}\right)\right\} \\
B_{f}= & \frac{1}{\bar{\omega}_{f}} \dot{\xi}_{f}(0)-\frac{1}{\bar{\omega}_{f} \omega_{f}^{2}} \sum_{i=1}^{n} 2 q_{1 i} \\
& \left(E_{2 i f}-4 E_{3 i f} \frac{\bar{\eta}}{\omega f^{2}}\right)+\frac{\bar{\eta}}{\bar{\omega}_{f}} A_{f}
\end{aligned}
$$

実際の計算にあたっては, 荷重の移動とともに式 (36) の係数 $a_{1} \sim a_{8}$ が変化するため, 微小時間間隔 $(\Delta t)$ に 対応する初期值接続の方法をとる. すなわち, 追跡段階 $K$ の場合の積分定数は, 式 (39) の $w_{\boldsymbol{f}}(x, y, 0), \dot{w}_{\boldsymbol{f}}$ $(x, y, 0)$ を $w_{f}^{K-1}(x, y, \Delta t), \dot{w}_{f}^{K-1}(x, y, \Delta t)$ とし て定め, $K$ 段階の $\Delta t$ 時間の解析を行うことになる.

\section{5. 道路橋床版の自由振動}

計算の対象とした橋梁は, (1) 支間 $29.2 \mathrm{~m}$ の 4 主桁 合成桁橋と, (2) 支間 $23.9 \mathrm{~m}$ の PC・T 桁橋, および (3) 支間 $70.2 \mathrm{~m}$ の上路トラス橋である.

\section{(1) 桁橋の自由振動}

図一5 に 4 主桁単純合成桁橋の 諸元を示す. 死荷重 


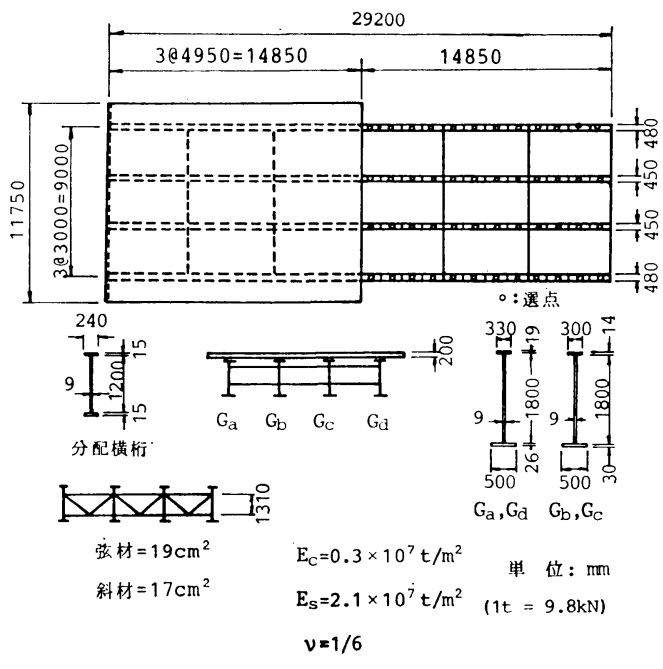

図一5 合 成 桁 橋
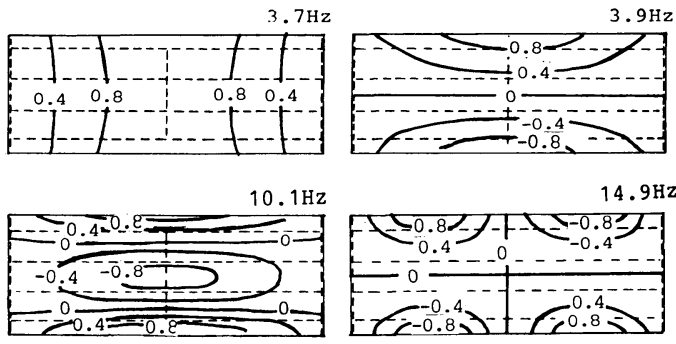

$14.9 \mathrm{~Hz}$
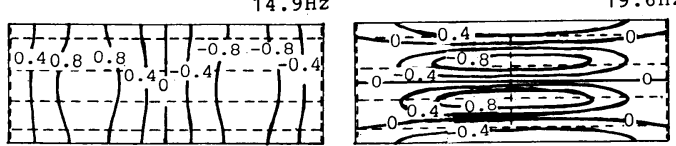

$16.7 \mathrm{~Hz}$

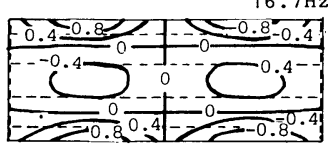

(a) 幅員方向正対称
$21.4 \mathrm{~Hz}$

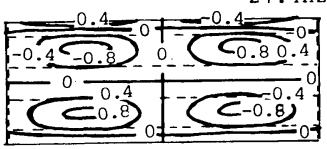

(b) 幅員方向逆対称
図一6 固有振動モード

は, 床版部で $0.76 \mathrm{t} / \mathrm{m}^{2}\left(7.4 \mathrm{kN} / \mathrm{m}^{2}\right)$, 主桁で $0.28 \mathrm{t} / \mathrm{m}$ $(2.7 \mathrm{kN} / \mathrm{m})$, 分配横桁で $0.14 \mathrm{t} / \mathrm{m}(1.4 \mathrm{kN} / \mathrm{m})$, 中間対 傾構で $0.06 \mathrm{t} / \mathrm{m}(0.6 \mathrm{kN} / \mathrm{m})$ である. なお, 下横構の重 量に相当するものとして $0.08 \mathrm{t} / \mathrm{m}(0.8 \mathrm{kN} / \mathrm{m})$ を主桁 に加算した. 次に中間対傾構の代わりに変形が等価な, 置換ばり（換算した断面 2 次モーメントは $0.00135 \mathrm{~m}^{4}$ である）を導入し，分配桁として扱った．また，本橋の 場合, 床版端部の沈下は無視し得るものと考え, 単純支 持として扱っている. 図一6には，応答解析に用いた固 有モードのうち, 幅員方向 3 次, 橋軸方向 2 次までを含 む， 8 種類のモードを示してある. 解析による基本振動 数の值は $3.7 \mathrm{~Hz}$ であった.これに対し実測值は $3.9 \mathrm{~Hz}$ で, 解析值より若干大きいが，これは実験上の誤差のほ
か，実橋の場合，舗装，高欄，あるいは横構などによる 剛性の影響も存在するためと思われる.いま，本橋のモ デルとして簡単に単純ばりを考え固有振動数を求めてみ ると， $3.9 \mathrm{~Hz}$ となることから基本振動モードは，ほぼ， はりのものに対応することがわかる. しかし，はりの 2 次モードに対応する振動数 $14.9 \mathrm{~Hz}$ のモードに至るま でに，床版ならびに横桁の分配作用によって，2つのモ 一ドが含まれ，後に述べる強制振動の場合には，これら の振動モードが合成されるために，応答は複雑になる.

次に，図一7 に PC·T 析橋の諸元を示寸. 死荷重は, 床版部で $0.76 \mathrm{t} / \mathrm{m}^{2}\left(7.4 \mathrm{kN} / \mathrm{m}^{2}\right)$, 主桁で $0.84 \mathrm{t} / \mathrm{m}(8.2$ $\mathrm{kN} / \mathrm{m})$ ，横析で $0.44 \mathrm{t} / \mathrm{m}(4.3 \mathrm{kN} / \mathrm{m})$ である. 本橋の 場合も，床版端部の沈下を無視し得るものと考え，単純 支持として扱っている. 図一8 には，応答解析に用いた 固有モードのらち，橋軸方向 2 次までを含む 8 種数のモ 一ドを示してある. 基本振動数の解析值は $3.5 \mathrm{~Hz}$ であ

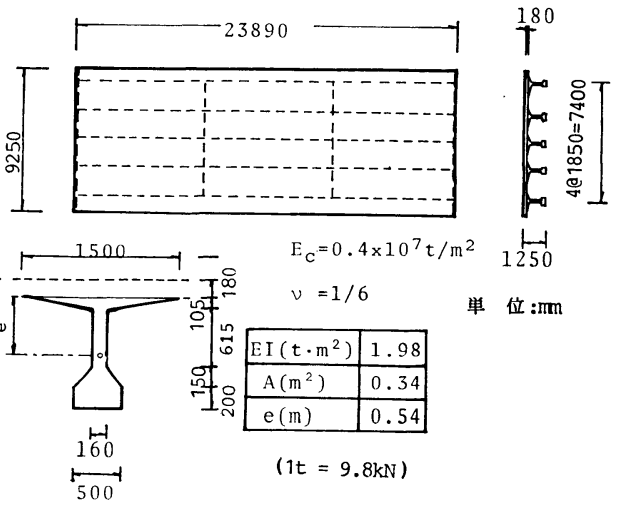

図-7 PC·T 桁橋

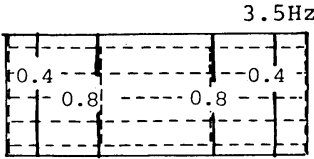

8. $4 \mathrm{~Hz}$

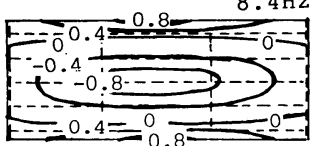

$13.8 \mathrm{~Hz}$
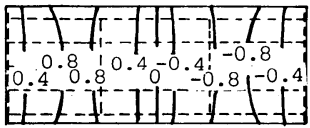

$18.4 \mathrm{~Hz}$

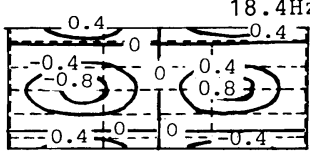

（a）幅員方向正対称
$3.8 \mathrm{~Hz}$

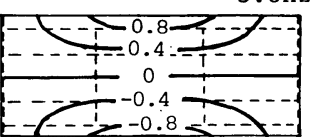

$14.2 \mathrm{~Hz}$

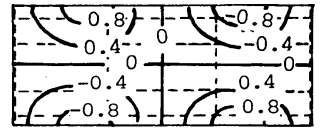

$18.4 \mathrm{~Hz}$

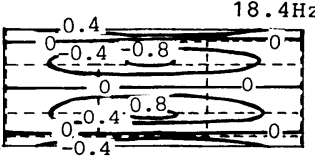

- $28.1 \mathrm{~Hz}$

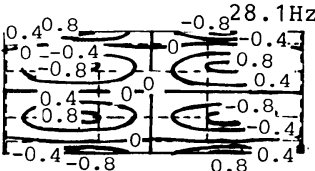

(b) 幅員方向逆対称

図一8 固有振㔚モード 
った.これに対し実測值は $4.5 \mathrm{~Hz}$ であるが，前 述の合成析橋の場合と同様な理由による差異と思 われる.

\section{（2）上路トラス橋の自由振動}

低周波空気振動の発生が初めて報告された道路 橋は, 上路トラス橋であり, 車両が伸縮継手を通 過する際に低周波音を放射していることが実測さ れている.ここで扱った事例では，横析は床版に 非接触の構造となっており，図一9に示すよう に, 橋の端部を車両が通過する際, 荷重は縦桁か ら端対傾構に伝達され, 端対傾構は鉛直ばねのような構 造となると考えられる. そこで, トラス主構部の垂直材 を, 図一10 に示す鉛直ばねを含む構造にモデル化し, さらに伸縮継手の沈下を考慮し, 曲げに対して自由な条 件を作り出すために，床版には 図一12 に示すような， 解析上の補助領域を設けている. 前述のように, 本解析 は, いわゆる積分法によるものであるから, 解法の性格 上, 補助領域の長さは, 継手の沈下を生ずる高次モード に対して，十分境界条件を満足するように定められねば ならない. 試算の結果, ここでは, その長さを $3 \mathrm{~m}$ と した. なお, 主構は等価な剛性 (伸び剛性, 曲げ剛性, せ ん断剛性）をもつはりに置換している. 図一11 は, 置 換ばりの剛性を定める手段を示したもので，ここで $\delta_{1}$, $\delta_{2}$ は，それぞれ弦材，および斜材の軸変形に 起因する

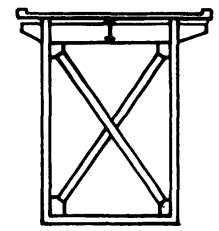

図一9 端対傾櫵

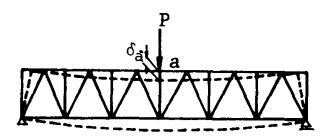

トラスのたわみ $\left(\delta_{a}\right)=\delta_{1}+\delta_{2}+\delta_{3}$

$\delta_{1}=$ 弦材の変形によるたわみ

$\delta_{2}=$ 斜材の

$\delta_{3}=$ 垂槙の "

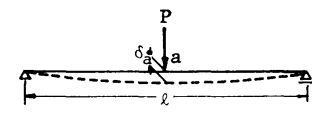

等価ばりのたわみ $\left(\delta_{a}\right)=\delta_{M}+\delta_{Q}$

$\delta_{M}=$ 曲 变形 $=\frac{P \ell^{3}}{48 E I}$

$\delta_{\mathrm{Q}}=$ 世ん断变形 $=\frac{\mathrm{P} \ell}{4 \mathrm{GJ}}$

(a) 等価㓮度の算定方法
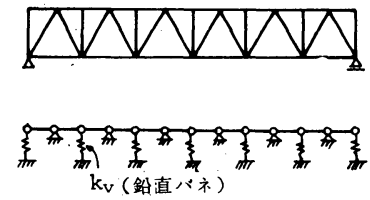

図一10 垂直材のモデル化
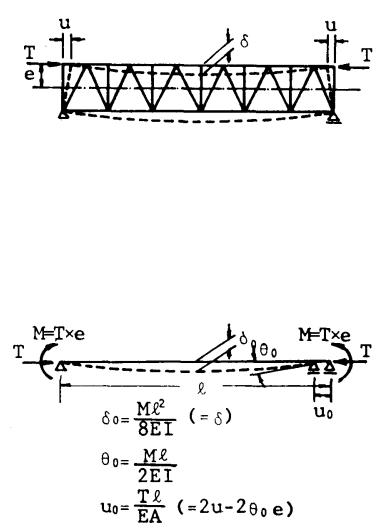

(b) 重心位罩およひ 等価断面㮔の定方法

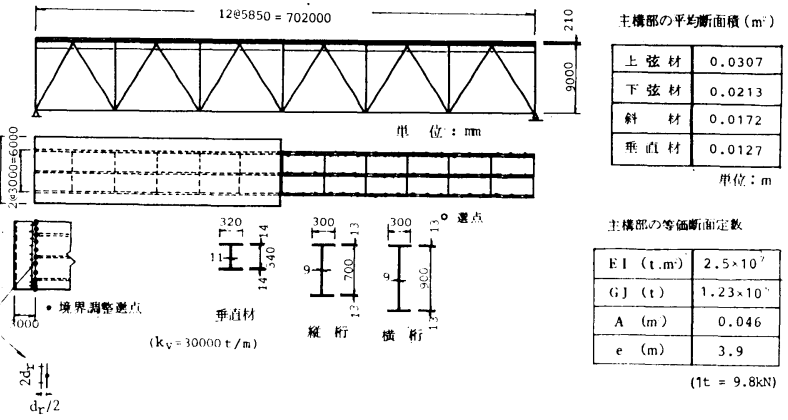

図一12上路トラス橋

変位量であり,それらは置換ばりにおける曲げ変形, な らびにせん断変形と考えることができる.したがって， 等価なはりの曲げ剛性 $(E I)$, ならびにせん断剛性 $(G J)$ は，それぞれ $P l^{3} / 48 \delta_{1}$ ，および $P l / 4 \delta_{2}$ のように与えら れる. さらに, $\delta_{3}$ は垂直材の軸変形に起因するもので, 前述のように鉛直ばねで置換している.すなわち床版と 合成される上弦材の変形は, 置換ばりによる変形に, 図 一10 のモデルによる 局所変形を加算して 近似すること ができる. 解析の対象とした上路トラス橋の諸元は, 図 -12 に示すとおりであり, 死荷重は床版部で $0.90 \mathrm{t} / \mathrm{m}^{2}$ $\left(8.8 \mathrm{kN} / \mathrm{m}^{2}\right)$, 主構で $0.73 \mathrm{t} / \mathrm{m}(7.1 \mathrm{kN} / \mathrm{m})$, 繸桁で 0.11 $\mathrm{t} / \mathrm{m}(1.1 \mathrm{kN} / \mathrm{m})$, 中間横析 で $0.13 \mathrm{t} / \mathrm{m}(1.2 \mathrm{kN} / \mathrm{m})$ であ る. また, 横構および中間対傾構の重量に相当するもの として, $0.40 \mathrm{t} / \mathrm{m}(3.9 \mathrm{kN} / \mathrm{m})$ を主構重量に加算した. ところで, 本橋の場合, 主構部では $\delta_{1}$ に対する $\delta_{2}$ の比 率が，ほぼ 0.5 となるのでせん断変形を無視できない. また, 振動問題では, 高次モードになるに従って, ノー ド間の距離が短くなり，せん断変形の影響がさらに大き くなると考えられる. 図一13 は, 主構部の 自由振動の 直接の解析結果と, 主構部を置換ばりとして扱った場合 のそれを比較したものであるが, 置換ばりでも, せん断 変形を考慮すれば実用上十分な精度で評価し得るようで ある. 図一14 に応答解析に用いた， 25 次までの固有振 動モードを示す.なお, 解析では, 車両が幅員中央を走

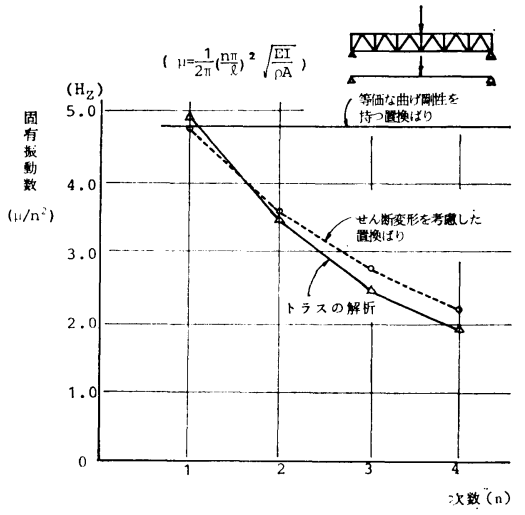

図一13 主鹤の固有振動数 

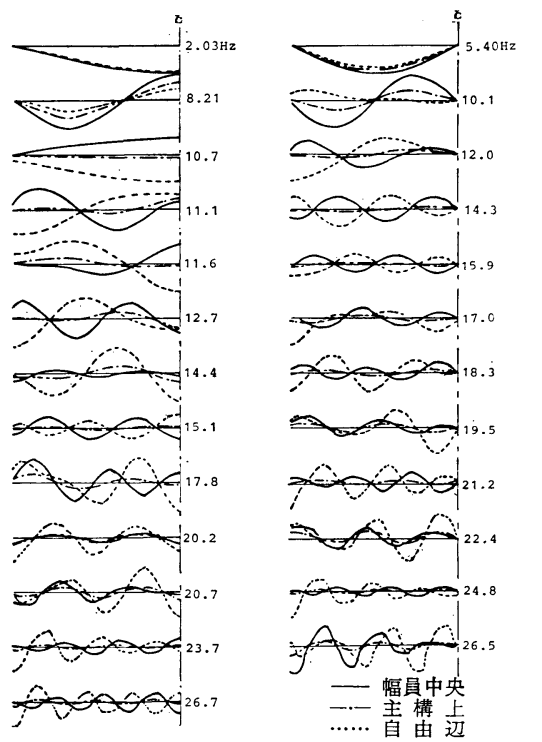

……主自構
(a) 橋軸方向正対称
(b) 橋軸方向逆対称

図一14 固有振動モード

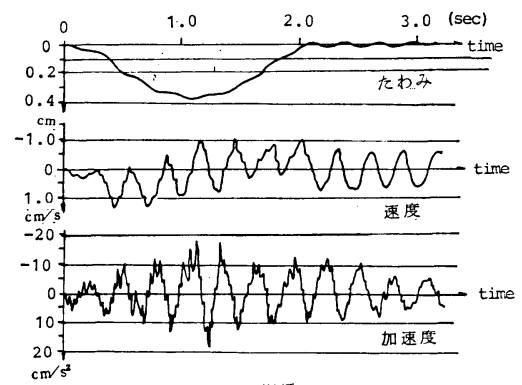

(a) 合成析橝

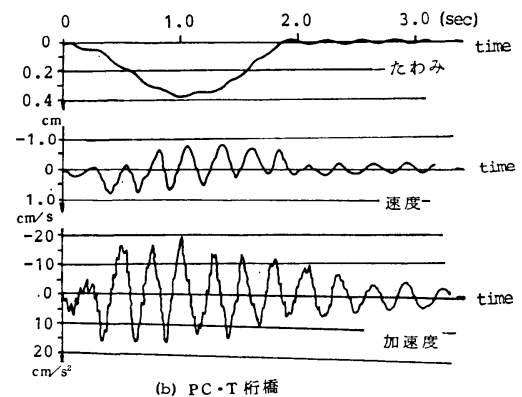

(b) PC・T 析橋

図一17标橋の応答波形
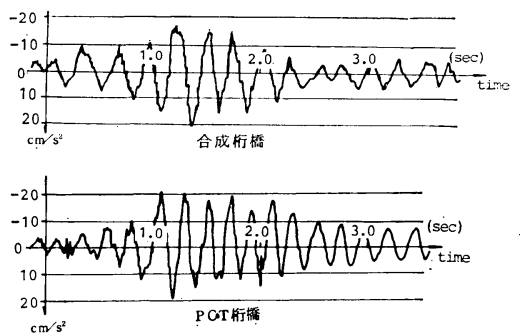

図-18 加速度波形の実測結果
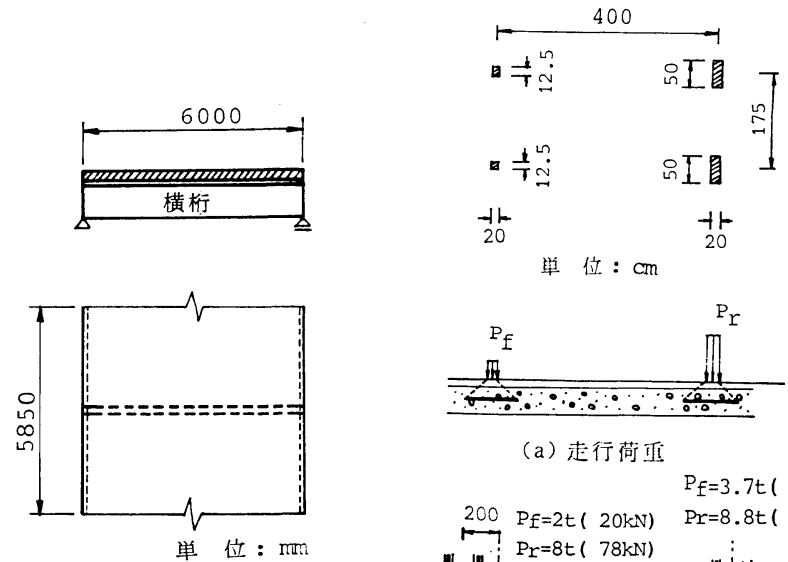

単 位： cm

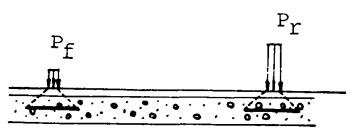

（a）走行荷亚

$P_{f}=3.7 t(36 \mathrm{kN})$

単 位：mm

図-15

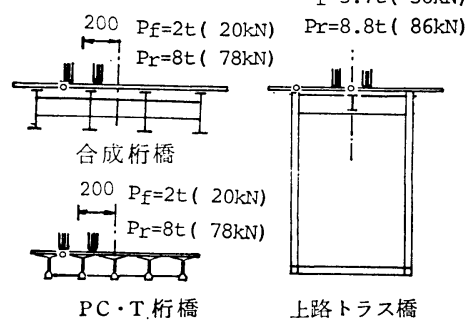

$\circ$ : 着目点

(b) 車両走行位羁之着目点

図一16車両走行荷豆
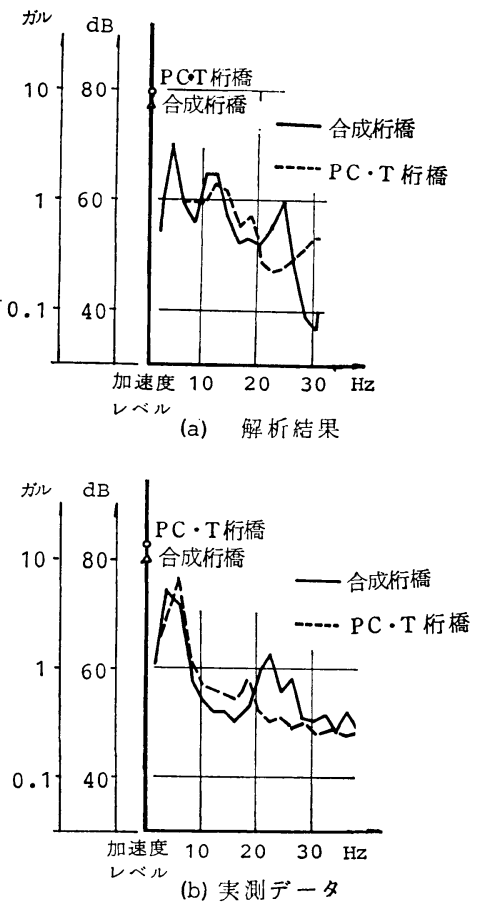

図一19 周波数分析結果

行する場合を扱ったので, 解析上必要な振動モードは, 幅員方向に正対称なモードのみである. 基本振動数の解 析值は $2.0 \mathrm{~Hz}$ であった.これに対し，実測值は $2.5 \mathrm{~Hz}$ で, 解析值より若干大きいが,（1）に示した析橋の場合 
と同様な理由によるものと思われる. また， $10 \mathrm{~Hz}$ 程度 までのモードは, 床版端部が単純支持の状態に近いが, それ以上の次数のモードには, 床版端部の 沈下が現わ れ, 幅員方向のモードは, 主構部が節となるような形に なる. 参考のために, 図一15に示すような, 横桁と床版 の重ねばりについて, 基本固有振動数を求めてみると約 $15 \mathrm{~Hz}$ となり, 端部の沈下が現われる振動数に対応して いる.

\section{6. 道路橋床版の動的応答}

図一16に，輪荷重の大きさと，それぞれの 橋梁にお ける走行位置, および応答解析の着目点を示した. な お, 走行速度は $50 \mathrm{~km} / \mathrm{h}$ である.

加速度レベルは,

$$
L=20 \log _{10} \frac{G}{10^{-5}}
$$

で表わし， $10^{-5} \mathrm{~m} / \mathrm{s}^{2}\left(10^{-3}\right.$ ガル）を基準にした.ここ に, $G$ は加速度の実効值 $\left(\mathrm{m} / \mathrm{s}^{2}\right), L(\mathrm{~dB})$ は加速度レベ

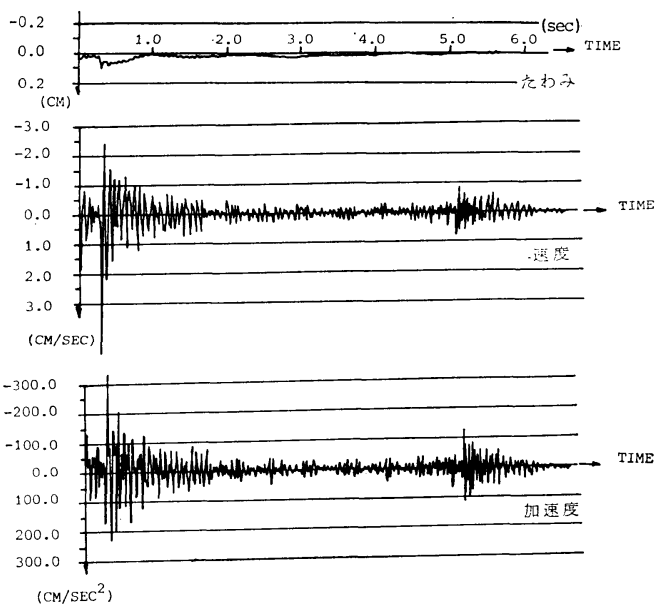

（a）伸 縮 継手 (A点)（進入側）
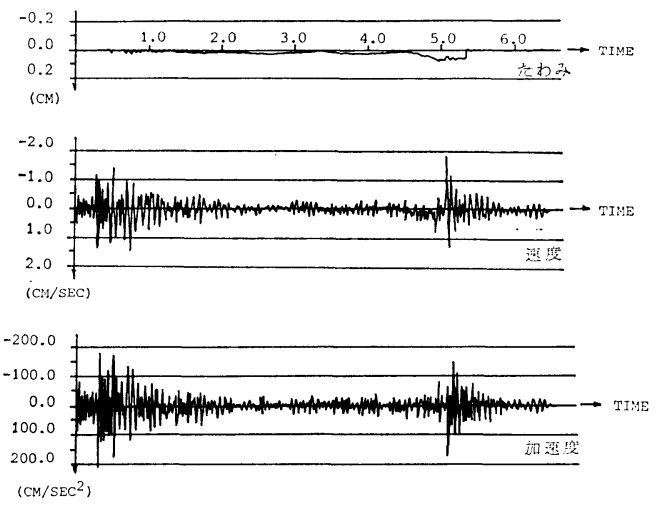

（c）伸縮 継手 (C点) (離脱側)
ルである.なお, 応答波形の周波数分析には, 波形 $f(t)$ を, 区間 $T$ の周期関数とする, 次の展開式を用いた.

$$
f(t)=\frac{a_{0}}{2}+\sum_{n=1}^{\infty} \sqrt{a_{n}^{2}+b_{n}^{2}} \cos \left(n \omega \bar{t}-\theta_{n}\right)
$$

ここに，

$$
\begin{aligned}
& \omega=\frac{2 \pi}{T} \\
& a_{n}=\frac{2}{T} \int_{-T / 2}^{T / 2} f(\bar{t}) \cos n \omega \bar{t} d \bar{t} \\
& b_{n}=\frac{2}{T} \int_{-T / 2}^{T / 2} f(\bar{t}) \sin n \omega \bar{t} d \bar{t}
\end{aligned}
$$

また, $\bar{t}=t-t_{1}\left(t_{1}\right.$ は分析区間の中心時刻) であり, 式 (41) の $n$ 番目の波形は, 周期が $T / n$, 振幅が $\sqrt{a_{n}{ }^{2}+b_{n}{ }^{2}}$ となる。

\section{（1）桁橋の強制振動}

合成桁橋，および $\mathrm{PC} ・ \mathrm{~T}$ 桁橋のスパン中央の応答波 形を, 図一17 に示す. 対数減衰率は, 実測值を参考に して 0.05 とした. なお, 式（36）の係数を定めるため

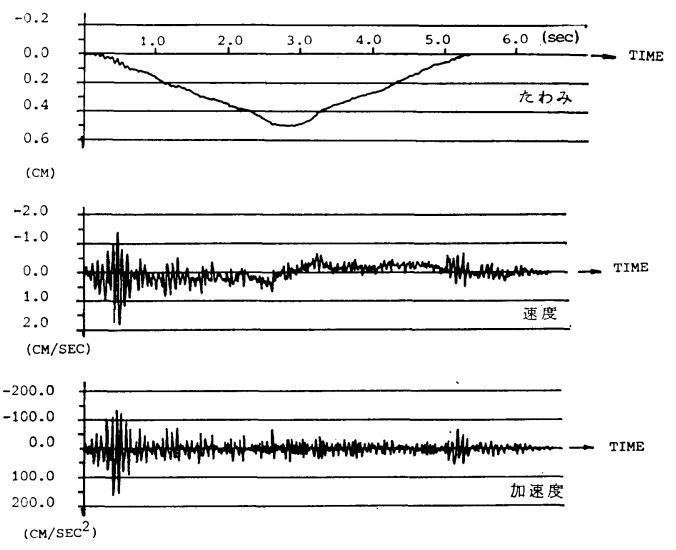

（b）支間中央（B点）
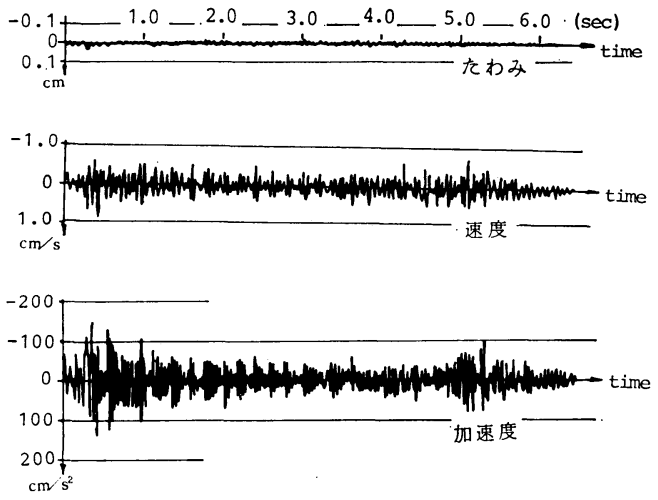

（d）主構上伸縮継手 ( $\mathrm{A}^{\prime}$ 点) (准入側) 
に必要な, 振動モードの解析点を橋軸方向に 24 点と り, 図一4(b) に示すネットの幅員方向の間隔は 0.875 $\mathrm{m}$ とした. また, 応答追跡の微小時間間隔は 0.0025 秒である. 図一18 は, 加速度波形の実測結果, 図一19 は, 周波数分析結果である. なお，これらの波形は前輪 が進入したときからのものである. 各橋梁とも, 基本周 波数が卓越し, 実測データの分析からも, 高次モードの 影響は小さく, 合成桁橋よりも PC・T 桁橋の方がより 小さい，なお，周波数分析のサンプリング区間は，後輪 が支間中央を通過する前後にとった 0.5 秒間としてお り,これは $2.0 \mathrm{~Hz}$ 以上のモードを分析できる間隔であ る (本橋の場合, 基本振動数は $3.5,3.7 \mathrm{~Hz}$ である). 解析の結果, 加速度レベルは $80 \mathrm{~dB}$ 前後と思われる.

\section{（2）上路トラス橋の強制振動}

前輪が進入したときからの, 床版振動の応答波形を図 -20 に示す. 対数減衰率は, 実測值を参考にして 0.1 とした. なお, 振動モードの解析点は, 橋軸方向に 36 点とり, 幅員方向には, ネット間隔を桁橋の場合と同様 とした. また, 微小時間間隔は 0.005 秒である. 車両 が伸縮継手を通過する際，たわみは $1 \mathrm{~mm}$ 程度である が, 速度, 加速度についてみると, 前輪, 後輪の進入に よる衝撃的な大きい振動が発生し, やがて減衰する.こ の振動は, 橋軸方向に伝播していき, 車両が反対側の端 部に進むにつれて減少する傾向がみられる，また，車両 が離脱する際にも，進入時よりは小さいが衝撃的な波形 が発生し, 反対方向に伝播している. なお, 主構上の応 答波形は, 版中央のものより，振幅は小さいが，橋軸 方向の波形の伝播には 同様の傾向がみられる. 図-21 に, 前輪進入時からの加速度波形の実測結果を示した. 実測波形も, 解析結果と同様な傾向を示すが, 高次モー ドの減衰は大きいようである. 次に, 床版の振動加速度 の周波数分析結果を示すと 図一22 のとおりである.な お, サンプリングの区間は, 車両の進入, および離脱時 には，それぞれ後輪が進入してから 0.5 秒間と，後輪 が出る前の 0.5 秒間であり, また, 支間中走行時は, 支間中央の着目点を後輪が通過する前後にとった 0.5 秒 間である.これは, $2.0 \mathrm{~Hz}$ 以上のモードを分析できる 間隔である（本橋の場合，基本振動数は $2.03 \mathrm{~Hz}$ であ る). 解析結果では, 進入時, および離脱時の加速度レ ベルは, それぞれ $95 \mathrm{~dB}$ と $87 \mathrm{~dB}$ となり, 卓越周波数 は $15 \sim 25 \mathrm{~Hz}$ である. また, 支間中央走行時の支間中 央での加速度レベルは, $87 \mathrm{~dB}$ で, 卓越周波数は, 基本 振動数の $2 \mathrm{~Hz}$, および $15 \sim 25 \mathrm{~Hz}$ である. 一方, 実測 データでは, 進入時, および離脱時の加速度レベルは, それぞれ $100 \mathrm{~dB}$ と $88 \mathrm{~dB}$ で, $15 \mathrm{~Hz}, 30 \mathrm{~Hz}$ の周波数 が卓越する. また, 支間中央走行時のレベルは $87 \mathrm{~dB}$

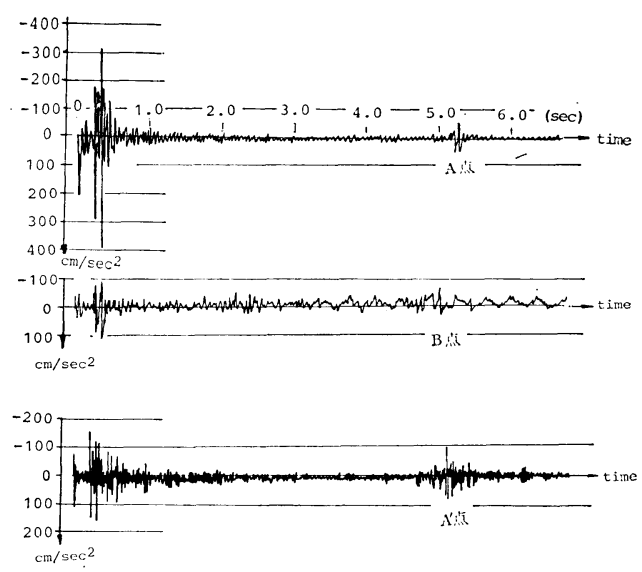

$\mathrm{A}:$ 進入側伸縮継手（幅員中央）

$\mathrm{A}^{\prime}:$ （主構上)

$\mathrm{B}:$ 支間 中 央 (幅員中央)

図一21 加速度波形の実測結果
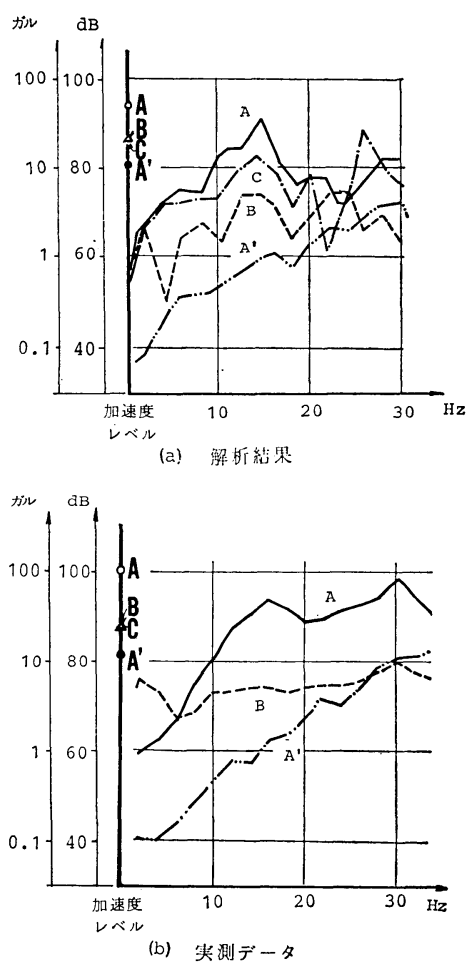

$\mathrm{A}$ ：進入側伸縮継手（幅員中央）

$\mathrm{A}^{\prime}$ : " （主構上）

$\mathrm{B}:$ 支間中央（幅員中央）

$\mathrm{C}:$ 離脱側伸縮継手（幅員中央）

\section{図-22 周波数分析結果}

で, 卓越周波数は $2.5 \mathrm{~Hz}, 30 \mathrm{~Hz}$ である. 次に, 主構上 の伸縮継手での振動レベルは, 幅員中央の点より, 解析 結果で約 $15 \mathrm{~dB}$, 実測結果で約 $20 \mathrm{~dB}$ 減少しており, 床版の曲げ振動が発生していることがわかる.

以上の上うに, 合成桁橋, $\mathrm{PC} \cdot \mathrm{T}$ 桁橋, 上路トラス橋 
のそれぞれについて, 特に, 低周波域 (30 Hz 以下) に おけるスラブの振動性状を実測值と比較したが，本解析 值は定性的かつ定量的に，ほぼ妥当な結果であると思わ れる。

\section{7. まとめ}

本研究で得られたおもな結論を以下に示す.

（1）検討の対象とした橋梁の基本固有振動数の解析

\section{表一2 基本固有振動数}

\begin{tabular}{l|c|c|c}
\hline 橋 & 梁 & $\begin{array}{c}\text { 支(間 } \\
(\mathrm{m})\end{array}$ & $\begin{array}{c}\text { 振 動 数 } \\
(\mathrm{Hz})\end{array}$ \\
\hline 合 成 析 & 29.2 & $3.7(3.9)$ \\
$\mathrm{PC}$ T 桁 & 23.9 & $3.5(4.5)$ \\
上路トラス & 70.2 & $2.0(2.5)$ \\
\hline
\end{tabular}

( ) 内は実測值
值ならびに実測值をまと めると表一2のとおりで ある. 解析值は支間 25 〜30 m の桁橋では約 $3.5 \mathrm{~Hz}$ ，支間 $70 \mathrm{~m}$ の上 路トラス橋では $2.0 \mathrm{~Hz}$ となり，実測値より若干

低い值となった.

（2）振動加速度レベルをまとめると表一3 のとおり である. 加速度レベルの解析値は, 実測值とほぼ一致し ており, 大型車両の 走行による加速度レベルは, 支間 25 30 m の桁橋では $80 \mathrm{~dB}$ 程度と思われる. 一方, 支 間 $70 \mathrm{~m}$ の上路トラス橋では $90 \mathrm{~dB}$ 前後となり, 特に 伸縮継手に車両が進入したときに大きくなり，反対側の 端部に進むに従って減少する傾向がみられる。

表一3 振動加速度レベル（dB）

\begin{tabular}{c|c|c|c}
\hline \multirow{2}{*}{ 橋 } & $\begin{array}{c}\text { 支間中央走行時 } \\
(l / 2)\end{array}$ & \multicolumn{2}{|c}{ 伸 縮 継 手 通 過 時 } \\
\cline { 3 - 4 } & 進 入 時 $(o)$ & 離 脱 時 $(l)$ \\
\hline 合 成 桁 & $77.3(79.5)$ & - & - \\
$\mathrm{PC}$ ・ T 桁 & $79.6(82.5)$ & - & - \\
上路トラス & $86.7(87.4)$ & $94.6(99.5)$ & $87.2(88.0)$ \\
\hline
\end{tabular}

( ) 内は実測值, $l$ は支間長

（3）単純支持形式として扱った桁橋の応答波形は 表一2 の基本振動モードが卓越する. 一方, 上路トラス 橋では, 支間中央走行時には $2 \mathrm{~Hz}$ の基本振動モードの ほかに，15〜25 Hz が卓越し，また車両が伸縮継手を通 過する際には 15〜25 Hz が卓越する. 上路トラス橋の 実測データの周波数分析の結果では, 支間中央走行時に は $2.5 \mathrm{~Hz}, 30 \mathrm{~Hz}$ のものが卓越し継手の通過時には 15 $\mathrm{Hz}, 30 \mathrm{~Hz}$ であった.

（4）本文で扱った上路トラス橋では車両が伸縮継手 を通過すると，衝撃的な波形が現われ，これが橋軸方向 に伝播している.したがって，このような橋梁の振動に 伴う空気振動が橋梁全体から放射される結果になると考 えられる。

（5）上路トラス橋の橋軸直角方向の振動についてみ ると, 車両が伸縮継手を通過するとき, 幅員の中央で加 速度レベルが高く，主構上で低くなることから，床版の
曲げ振動が発生していることがわかる．したがって音響 制御上の対策として, 継手部分の横桁の補強が考えられ る.また継手より誘発される振動が，伝播によって橋梁 全体から放射されると考えられることから，継手部のみ ならず，中間部での横桁の補強も必要ではないかと思わ れるが,これらについては, 今後の検討課題としたい.

本研究は, 走行車両による道路橋床版の振動特性を, 最近, 環境問題の 1 つとしてクローズアップされている 低周波域に着目し，特に音響制御的な観点に立って，探 究したものである. 従来, 走行車両による橋梁床版の振 動の研究のほとんどのものが, 主として強度的な観点に 立っており, 本研究のように音響制御的な観点に立った ものは数少ない. 土木における 音響制御の 分野の問題 は，建築などの分野と異なり，やはり土木固有の構造物 にかかわる問題であり, 今後さらに検討されるべき課題 であるといえる．橋梁床版の 低周波域の 振動に関して は，まだ不明の点もあり，本研究では，実測值のある事 例についての解析を行ってその妥当性を確かめたもの で，本文に示した成果は，この分野における 1 つの基礎 的なデータとして寄与し得ると考えている.

\section{参 考 文 献}

1）成岡昌夫・平井一男 : 走行荷重による短形板の振動に関 する一研究, 土木学会論文集, 第 32 号, pp. 40 42, 1956.

2) 平井一男 : 移動荷重をうける 相対 2 辺単純支持, 他の 2 辺自由なる直交異方性板の 振動性状について, 土木学会 論文集, 第 92 号, pp. $1 \sim 8,1963$.

3) Sundara Raja Iyengar, K.T. and K.S. Jagadish : The responce of beam and slab bridge to moving forces, Publ. of IABSE, Vol. 28, No. 2, pp. 69 86, 1968.

4) Sundara Raja Iyengar, K.T. and K.S. Jagadish : Dynamic responce of highway bridge to moving loads, Publ. of IABSE, Vol. 30, No. 2, pp. 57 76, 1970.

5) Yoshida, D.M. and J.R. William Weaver : Finite-element analysis of beams and plates with moving loads, Publ. of IABSE, Vol. 31, No. 1, pp. 179 195, 1971.

6) Srinivasan, R.S. and K. Munaswamy : Dynamic response of skew bridge decks, Earthquake Eng. Struct. Dynamics, Vol. 6, pp. 139 156, 1978.

7) Hutton, S.G. and Y.K. Cheung : Dynamic responce of single span highway bridges, Earthquake Eng. Struct. Dynamic, Vol. 7, pp. 543 553, 1979.

8）能町純雄・角田与史雄・大島俊之：橋梁の 走行荷重によ る低周波空気振動発振評価の一手法, 第 13 回日本道路会 議論文集, pp. 51～52, 1979.

9) Nomachi, S., T. Ohshima, Y. Kakuta and N. Kishi: On infrasound evaluation radiating from freeway bridge generated by a travelling load, Inter-noise 80 , Miami, Florida, U.S.A., pp. 527 530, 1980.

10) Kaneyasu, K., Y. Adachi, M. Koyasu and S. Shimizu: Investigations on the radiation of low frequency sound from highway bridge, Inter-noise 81, Amsterdam, Holland, pp. 321 324, 1981.

11）岡村宏一・進藤泰男 : 板と骨組の 合成構造の 振動の立体 解析, 関西支部年次学術講演会概要, p. I-27, 1971.

12）岡村宏一・吉田公憲・島田 功・進藤泰男 : 構造物の一 つの 弾性立体解析法とその 系統的応用, 土木学会論文報 告集, No. 190, pp. $61 \sim 74,1971$.

(1982.3.25 • 受付) 